\section{Business strategies in the context of poorly- delineated land property rights}

\author{
Carolina Torres Graça ${ }^{1}$ \\ Decio Zylbersztajn ${ }^{1}$ \\ ${ }^{1}$ University of São Paulo, Economics, Business, and Accounting Faculty, Business \\ Administration Department, São Paulo, Brazil
}

\section{Abstract}

Purpose - To understand the interconnection between the institutional environment, land conflicts, and business strategy under the lens of the Economic Analysis of Property Rights.

Design/methodology/approach - Qualitative analysis of academic publications and sustainability reports.

Findings - Identification of six categories of pathologies associated with land rights held by forest companies and four categories of strategic mechanisms employed by the same organizations.

Originality/value - To evidence through empirical data the interconnection between the institutional environment, land conflicts, and business strategy for land rights protection in Brazil.

Keywords - property rights; business strategy; land rights; forest industry; Brazil.
Received on

$01 / 28 / 2018$

Approved on

$12 / 26 / 2018$

Responsible editor:

Prof. Dr. Ignacio Canales

Evaluation process:

Double Blind Review

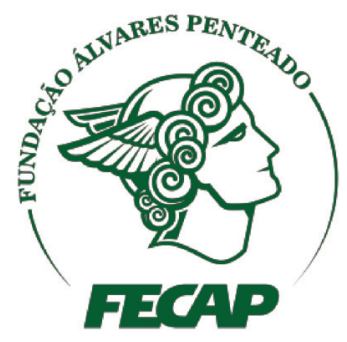

Review of Business Management 


\section{Introduction: Poor Legal Protection of Land Rights}

Good institutions are frequently associated with economic development (Acemoglu, Johnson, \& Robinson, 2001; de Soto, 2000; North, 1990). A legal framework that enables contract enforcement and protection of property rights also encourages investment and sustainable use of natural resources (Deininger \& Jin, 2007). On the other hand, when such conditions are absent, investment incentives are poor and economic development is limited (de Soto, 2000). Besides hampering investment and economic development, what are the consequences of fragile institutions for economic agents?

According to Dixit (2009), "if governments do not protect property rights, at least not as well as the owners require, many alternative private arrangements arise to meet the owner's needs". For Barzel (2002), the more expensive it is to draw up and enforce contracts through the state as the third party enforcer, the more people will use dispute-solving mechanisms that play the role of the state. The latter itself can create such substitute operations.

This paper is based on the assumption that the enforcement of agreements (or property rights) is a basic feature of the state (Barzel, 2002). With regard to land rights, the state is able to keep land records and advocate in disputes at a lower cost than using the testimony of members of the

\section{Section 2:}

The stewardship of property rights by the State

Figure 1 - Paper structure

community to confirm ownership (Barzel, 2002). Hence, it is the steward of land rights. However, poor quality institutions may attenuate legal protection. Under such conditions, some property rights are unclearly defined, which is equivalent to allocation into the public domain. As a consequence, agents spend resources to acquire them and, in reaction, owners take protective measures (Dixit, 2004).

The paper's structure (Figure 1) follows the theoretical rationale just mentioned. Section 2 explores the reasons for the attenuation of legal protection and its consequences. Section 3 explores institutional fragilities around land rights in Brazil. Section 4 details the methodological procedures. Section 5 explores disputes between forest companies and some groups of stakeholders for land rights, which are called pathologies due to them being recurrent. Protective measures deployed by three forest companies are explored in section 6, which is called business response to insecure land rights. The following session discusses the results, followed by the conclusion. The objective is to answer two questions: what are the pathologies associated with poor legal protection of land rights in Brazil and what are the strategies deployed by forest companies to deal with land disputes? The conclusion is built on qualitative analysis of two data sources: academic publications and business sustainability reports.

Section 4:

Land disputes between forest companies and stakeholders

\section{Section 5:}

Land rights protection by forest companies

\section{gilities for land rights} protection in Brazil
The plantation forest sector has been chosen for a few reasons. Firstly, the losses accumulated by only five companies have been estimated at US\$460 million up to 2015 (Graça, Reydon, Postal, Bueno, \& Moreira, 2017). Secondly, it is a relevant industry in Brazil in 
terms of occupied area, which is about 7.8 million hectares, and accounts for a $6.2 \%$ share of GDP (Indústria Brasileira de Árvores, 2017). Thirdly, all information on this industry is available to the public.

\section{Property Rights Protection}

What happens when property rights are poorly defined and enforced? This is the underlining question of the Economic Analysis of Property Rights, developed by Barzel (1989, 1997, 2002). The author leaves aside any legal analysis and concentrates on what he calls economic property rights. According to his theory, economic property rights are those exercised by economic agents in accordance with, in contradiction to, or even going beyond legal rights.

Incomplete definitions of property rights are frequent for many reasons. First of all, an asset is composed of many attributes, which can be owned by different persons (Barzel, 1997). Rights are linked to attributes, forming a bundle of rights. Since multiple owners share asset ownership, the definition of property rights is key to preventing disputes among them. Secondly, defining ownership is a resource consuming activity, therefore valuable attributes tend to have attached rights which are better defined than for less valuable attributes (Barzel, 1997). Thirdly, measurement and enforcement of property rights are also costly activities (Barzel, 1997). These three reasons explain why the definition of property rights is not exhaustive, leading to the allocation of rights into the public domain.

Property rights in the public domain are vaguely defined, and consequently poorly protected, creating the possibility of value capture without compensation to the due owner (Barzel, 1997). For this author, defining and protecting rights is a matter of choice. Owners choose to exercise rights whose gains surpass delineation, measurement, and enforcement costs. When the balance is (potentially) negative, they choose to let them to go into the public domain. This analysis is dynamic, which means that rights are recovered from or placed in the public domain any time that their perceived value changes (Barzel, 1997).

For the Economic Analysis of Property Rights, transaction means the exchange of property rights and value appropriation is preceded by value generation and capturing efforts. Therefore, Barzel (1997) defines transaction cost as the cost associated with the transfer, capture, and protection of property rights.

Bearing in mind that economic property rights are not entirely regulated by law, that ownership over an asset is shared among multiple owners, and that some rights are allocated in the public domain, economic agents (including organizations) strive to minimize transaction costs. One possible solution is to select an efficient ownership structure and impose restriction for shared owners (Barzel, 1997).

Although legal analysis is not the focus of the theory developed by Barzel, it does not neglect the relevance of formal institutions in reducing the portion of rights in the public domain and in improving the economic ownership of assets. In fact, enforcement of agreements is considered a basic feature of the state (Barzel, 2002).

Two types of economies of scale are linked to legal property rights protection, allowing the state to be the enforcer of various contracts. One category includes the economies of scale that arise in assembling the power needed for protection. The second is associated with the use of rulings applied when different groups of individuals make similar agreements and their causes of dispute are similar.

The more expensive it is to make and enforce contracts through the state, the more people will use dispute-resolving mechanisms that replace the former. As the state expands its scope of operations, it also expands its bureaucracy, placing itself at a disadvantage when providing disputesolving methods other than already available third-party enforcement. The more numerous and more valuable the activities in which the substitute mechanisms are cost-effective, the less the state can exploit the economies of scale for protecting 
and establishing legal rights. Some examples of substitute mechanisms are close-knit groups, vertically integrated firms, trade, and criminal organizations (Barzel, 2002).

For Dixit (2004, 2009), the government's failure to protect rights, and the violation of private property rights by the government or its agents (e.g., corruption), are major causes of poor economic performance in many countries, especially the less-developed ones. Other social institutions of economic governance also exist in almost all countries. They function especially in niches where the government provides poor services, or does not provide any service at all (Dixit, 2009). Governmental and private institutions of governance coexist. Therefore, it is important to find the combination between them that works well under each circumstance.

Formal institutions of the state carry out enforcement through its legal apparatus and by using its powers of coercion if needed as a last resort, and informal social institutions, which must be self-governing, use strategies available to the participants themselves in the economic interaction. For a law on the statute books to be effective in practice, citizens must expect the government to succeed in enforcing the law. Informal private and social institutions include networks that facilitate research and information, behavioral norms, and enforcement sanctions in cases of violations of norms (Dixit, 2009). Some of the private cases of economic governance explored by Dixit (2004, 2009) include integration and corporate governance, bilateral self-enforcement by a pair of agents, multilateral self-enforcement in a community of traders, private external enforcement by private adjudication, enforcement under the shadow of formal law, provision of information to be used as an input in second-party enforcement, and enforcement for profit by a third party.

Based on Barzel's theory, Zylbersztajn (2010) proposes that rights are protected by the interaction of legal and economic rights. The former are enforced by the state (formal property rights - FPR) and the latter are enforced by economic agents on their own (informal property rights - IPR). The sum of these two classes of protection can be $100 \%$, at the extreme, but since full protection is costly, their combination can often be below that ceiling. What is left unprotected (PRO) is in the public domain, and therefore susceptible to capture. Figure 2 illustrates the components of the property rights index (PRi).

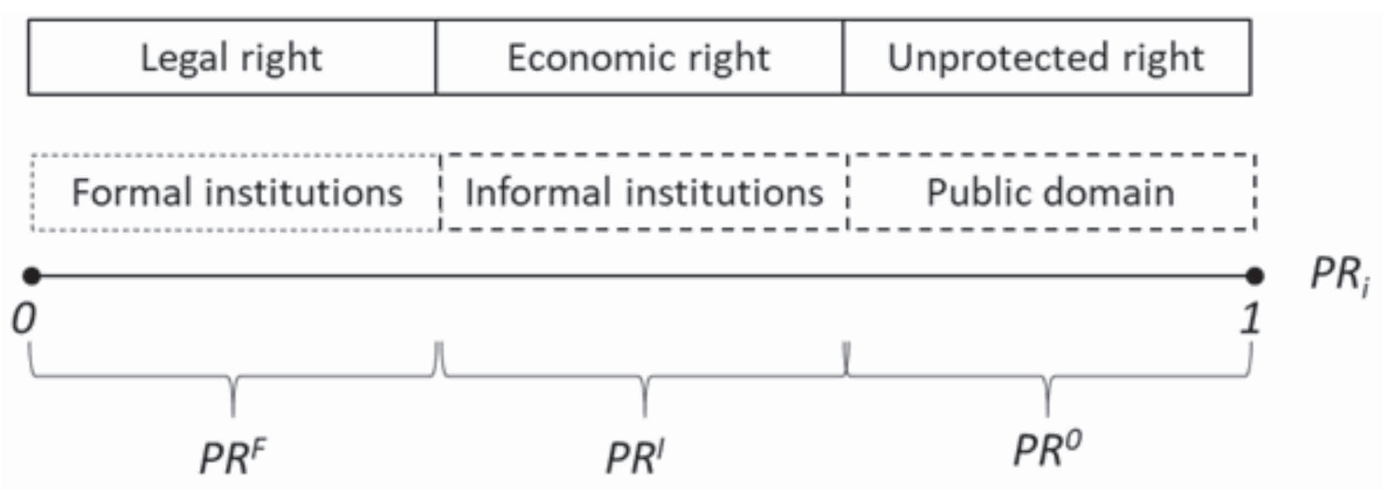

Figure 2 - Components os property rigts index (PRi)

Ultimately, transactions only take place in the presence of a minimal property right protection threshold (PRi), which means a small
PR0 share. In cases where PRi $<$ PRF, transactions are likely to take place via market mechanisms. When PRF $<$ PRi $<$ PRF + PRI, transactions 
rely on the combination of formal and informal mechanisms for property rights protection. Changes in the business environment may affect the distributions of these three shares, allowing PRF + PRI to fall below the threshold (PRi), thereby preventing transactions and/or allocating rights into the public domain. In this scenario, economic agents may engage in the revision of rights protected by formal and informal mechanisms in order to establish a new balance. Indeed, once individuals identify an opportunity for profit, they strive to create enabling conditions for the transaction to happen (Dixit, 2004).

In summary, some property rights over an asset can be unclearly delineated because there are costs involved in this activity. Therefore, they are allocated in the public domain. Theft and wealth capture can occur when delineation of rights is incomplete. Protection of rights can take various forms. The state protects property rights by employing legal mechanisms, supported by formal institutions; protection can also derive from private mechanisms, supported by informal social institutions. The two avenues are complementary and coexistent. There are circumstances where the state faces high costs or is not the appropriate protector, and so the role of private mechanisms becomes preponderant.

For the purposes of this paper, wealth capture is the motivation behind land disputes, and the private mechanisms for land rights protection are the strategies deployed by forest companies. Sections five and six explore land disputes in Brazil and business strategies, respectively.

\section{Reasons for Insecure Land Tenure in Brazil}

There are many reasons for insecure land rights in Brazil (Alston, Harris, \& Mueller, 2009; Araujo, Bonjean, Combes, Combes Motel, \& Reis, 2009; B. P. Reydon, Fernandes, \& Telles, 2015). The two most referenced in the literature are historical tension between de facto and de jure land rights, and lack of a sound land governance system. These factors result in a limited capacity of the state to define and enforce property rights.

Brazil's colonization was characterized by disputes between squatters or irregular landowners and the state. In colonial times, when land was abundant, possession of vacant land enabled peasants to access grounds and land owners to enlarge their properties (Silva, 1997). The tradition of claiming land has persisted over the years, despite many attempts by the state to regularize de facto landowners and limit further possession of vacant or public land (Reydon et al., 2015; Reydon, 2011, 2014; World Bank, 2014). The possession of land rights is assured by the current Constitution (Brazil, 1988).

During the 1990s, social movements emerged with the aim of promoting land reform (Reydon, 2014). Between 1995 and 2009, Brazil settled more than 1 million families on about 75 million hectares (Reydon, 2014). Despite this, from 2009 to 2015 the number of conflicts, families, and land surface involved increased dramatically (by 13\%, 50\%, and 42\% respectively) (Comissão Pastoral da Terra, 2016). This illustrates the tension around land disputes in the country.

The 1988 Constitution also acknowledged the land rights of indigenous people and Afrodescendent groups (Brazil, 1988). Since then, land demarcation has been taking place. In many circumstances, expropriation of private land has been necessary to compose Afro-descendants' territories.

The land registry and cadaster has numerous weaknesses, according to a study commissioned by the World Bank in 2014. Some of these are: the lack of integration between notaries (private organizations) and public agencies; the lack of an integrated cadaster of private and public land; the absence of a full public land inventory; low accuracy of land records (geo-referenced shapefiles were not a requirement for land registers until 2001), which has allowed multiple land titles issued in the names of different owners for a given piece of land, and ownership regularization based on fraudulent possession titles; out-of-date land 
registries, since registration is not compulsory by law; and finally, taxes on exchanges of property rights deter landowners from officially registering transactions regarding an asset (World Bank, 2014). All these weaknesses attenuate land right protection by the state.

Forest operations are embedded in this institutional environment. Despite competitive advantages associated with the mild climate, extensive surface, and technological development over the past 50 years (Indústria Brasileira de Árvores, 2017), insecure land rights imposes (transaction) costs on round log production in Brazil (Graça et al., 2017).

\section{Methodological Procedures}

This paper aims to answer two questions: what are the main pathologies associated with poorly protected land rights in the Brazilian forest sector and what are the strategies deployed by forest companies to protect land rights? The term pathology is used in the sense of recurrent disputes reported by the literature. Land disputes are those associated with land property rights, despite the existence of other concerns around forestry in the country, such as environmental and social concerns.

This study employed a qualitative analysis of academic publications and sustainability reports due to the need for an in-depth understanding of the problem (Yin, 2010). The first source of information allowed for the identification of pathologies and the second identified the business strategies for the protection of land rights.

\section{I Review of academic publications}

This phase was carried out between January 2017 and April 2018. It consisted of screening papers published between 2007 and 2018, using a combination of entries such as "land conflict", "land tenure", "land rights", "forest companies", "forest sector", "paper industry", and "Brazil" (using "and" between the entries) on the publication database Web of Knowledge. A total of 85 papers were retrieved. During the abstracts review, papers were identified containing the words "eucalyptus" or "pine" (to select papers about the forest plantation sector) and using the words "land" and "conflict" semantically connected to each other (in some cases, both words were used in the paper but disconnected from each other). After the second screening phase, fifteen papers were selected. Thirdly, six papers were eliminated for being duplicated. Two papers were eliminated because their full texts were not available. In the end, seven papers were selected for the full text review. The authors also searched for the same entries in Portuguese, but no publications were retrieved from the Web of Science database.

It was noted that the same author wrote five out of those seven papers; therefore, to counterbalance his work, five other papers, one doctoral thesis, and one master's thesis were included in the literature review. These publications were retrieved during the literature review phase from the Sibi database (Sistema Integrado de Bibliotecas Universidade de São Paulo). In all of them it was possible to find the same combination of entries in English just listed or the same entries in Portuguese ("conflito fundiário", "direito de posse", "direito sobre a terra", "empresas florestais", "setor florestal", "indústria de papel”, and "Brasil"). However, it is important to mention that the publication selection from Sibi was not an exhaustive search. Publications were selected in accordance to their adherence to the object of study.

In total, twelve papers and two theses were the sources of information for the literature review.

The data was systematized in two tables: (1) number of papers where the forest company names were mentioned and (2) land disputes mentioned in the paper. Land disputes were systematized using eight categories: land disputes with the indigenous community, land title regularization and land acquisition facilitation, land disputes with Afro-descendent groups, land disputes with the local community, land claimed by the landless movement, possession of public 
land, and superposition of land titles. The authors used charters and classifications employed by the papers reviewed to propose these eight categories.

\subsection{Document analysis of sustainability reports}

Document analysis searches for explicit information in the document under analysis (Dellagnelo \& Silva, 2005)"title":"Análise de conteúdo e sua aplicação em pesquisa na admin istração","type":"chapter"],"uris":["http://www. mendeley.com/documents/?uuid=dd0345f4-259e47b1-92e0-eb8187167b55”]\}]," mendeley": ‘“for mattedCitation":"(Dellagnelo \& Silva, 2005. The information was retrieved from the sustainability reports of the top three Brazilian companies most cited by the literature review, which were available on their webpages. Reports for 2015, 2016, and 2017 were reviewed, except for Veracel, whose 2017 report was not available by May 2018. The key words "stakeholders", "community", "communitarian", "land", "ground", "property", "conflict", and "dispute" (in Portuguese: "partes interessadas", "comunidade", "comunitário", "terra", "solo", "fundiário", "conflito" and "disputa") were employed to track the parts of the report with relevant information. Whenever those key words were found, the context and meaning were analyzed in order to identify strategies to protect land rights.

According to Barzel (1997), given that some property rights are not completely defined, there is some space for capture attempts by one agent without paying due compensation to the creator or owner of such rights. Based on this proposition, the authors of this paper deployed four possible solutions to clarify blurred property rights: (a) clarification, upholding, or definition of rights between the parties; (b) reallocation of rights between the parties; (c) appealing to a third party to define and enforce property rights; and (d) a combination of strategies a, b and c. Category "d" was created because some initiatives serve multiple purposes simultaneously. The results were summarized in a table, including the year of the report where the information was retrieved.

\section{Main Pathologies Linked to Insecure Land Rights in Brazil}

Since the poor quality of institutions in Brazil attenuates legal land rights protection, as explored in session 3, some pathologies emerge. The problem involves landowners across the country, including those in the forest sector, given its dependence on large tracts of forest to supply pulp mills.

According to the review of academic publications, the most frequent land disputes associated with forest plantation companies in Brazil are: disputes with local communities (cited by 8 publications), disputes with indigenous communities (cited by 7 publications), criticisms around land title regularization and land acquisition facilitation by the government (cited by 7 publications), disputes with the landless movement (cited by 6 papers), land disputes with Afro-descendent groups (cited by 4 publications), possession of vacant public land (cited by 4 publications), and superposition of land titles (cited by 1 paper) (Table 1 ).

Table 1

Land disputes associated with forest companies in Brazil and number of publications they were mentioned in

\begin{tabular}{lc}
\hline Land disputes & \# of publications \\
\hline Land disputes with the local community (motivated by the occupation of land previously cultivated by this community) & 8 \\
Land disputes with the indigenous community & 7 \\
Land title regularization and land acquisition facilitation & 7 \\
Land disputes with the landless movement & 6 \\
Land disputes with Afro-descendent groups & 4 \\
Possession of public land & 4 \\
\hline
\end{tabular}


Land disputes with local communities are connected to land possession practices. In Brazil, it is a common practice, for which there are legal provisions, to occupy and cultivate land independently of having the deed. The occupation of private and vacant public land is frequent. Various authors (Fig, 2007; Gerber, 201 1; Graça et al., 2017; Kröger, 2012, 2013, 2014; Kröger \& Nylund, 2012; Malina, 2013) suggests that squatters have been evicted from farms by land owners previously to land acquisition by forest companies.

Land disputes with the indigenous community are rooted in the political history of indigenous peoples' rights. Before land demarcation, indigenous groups disputed over land with farmers and companies (Fig, 2007; Gerber, 2011; Malina, 2013). In some cases, the establishment of indigenous territories was a long and painful process (Fig, 2007; Graça et al., 2017). It was reported that indigenous residents have been deceived by land dealers and persuaded to move to other regions (Malina, 2013).

According to the literature review, from the thirties to the nineties, forest sector development was encouraged by the government (Kröger, 2012; Kröger \& Nylund, 2012; Malina, 2013) as a strategy to reduce dependency on the importation of pulp and paper products and to generate an exportable surplus (Malina, 2013). Among other incentives, the government has facilitated land acquisition (Graça et al., 2017; Malina, 2013) and regularization by forest companies (Claro, 2007; Graça et al., 2017; Malina, 2013), especially by stated owned companies such as Vale do Rio Doce (Kröger, 2012).

The dispute with the Landless Worker's Movement (in Portuguese: MST - Movimento dos Trabalhadores sem Terra) is motivated by three factors: (a) acquisition of farms considered to be unproductive, and therefore eligible to dispossession for land reform (Graça et al., 2017; Kröger, 2011, 2012; Kröger \& Nylund, 2012; Malina, 2013); (b) land price appreciation, consequently stalling agrarian reform in wood sourcing regions by pulp mills (Kröger \& Nylund, 2012); and (c) acquisition of land with possession titles, which is considered by this movement to be vacant public land since the farms have not been officially detached from public assets (Kröger, 2012; Kröger \& Nylund, 2012; Malina, 2013). The literature also mentions investigations or actions taken by authorities to refrain the possession of vacant public land by private companies (Claro, 2007; Malina, 2013)

Disputes with Afro-descendent groups are also rooted in the lack of legal recognition of the traditional community's right to the land. The absence of land titles has historically made the group vulnerable to land eviction and loose protection of tenure rights (Graça et al., 2017; Malina, 2013).

Finally, superposition of land titles is associated with one company in the Northeast part of the country, where land governance is even more fragile (Graça et al., 2017).

Based on the same group of publications, the company associated with the land conflicts with the largest number of citations was Aracruz and/or Fibria1 (cited by 9 publications), followed by Suzano and Veracel (cited by 8 publications each), then Jari (cited by 4 publications), Stora Enso (cited by 3 publications), and International Paper and Cenibra (cited by 2 publications each) (Table 2). The companies are located across Brazil, from North (Jari) to South (Stora Enso), but three of them have operations in the South Bahia region (Fibria Aracruz unit, Suzano Mucuri unit, and Veracel).

Table 2

\begin{tabular}{lc}
$\begin{array}{l}\text { Forest companies in Brazil associated with } \\
\text { land disputes according to the literature }\end{array}$ \\
$\begin{array}{l}\text { review and number of publications they were } \\
\text { mentioned in }\end{array}$ \\
\hline Company name & \# of publications \\
\hline Aracruz or Fibria & 9 \\
Suzano & 8 \\
Veracel & 8 \\
Jari & 4 \\
Stora Enso & 3 \\
Cenibra & 2 \\
International Paper & 2 \\
\hline
\end{tabular}

Since Fibria, Suzano and Veracel were the most frequently cited organizations, it is assumed 
that they are the organizations that are most exposed to the pathologies identified here. As a result, they are expected to implement protective measures. The next section explores their strategies to protect land rights.

\section{Business Responses to Insecure Land Rights in Brazil}

Responsible businesses strive to balance the social, environmental, and economic outcomes of their activities, aiming to meet the interests of their stakeholders (Elkington, 1994). In this spirit, it is desirable for companies to favor negotiating an agreement before resorting to legal mechanisms for rights protection. To achieve this goal, forest companies have developed ad hoc strategies to deal with and solve land disputes.

Based on the review of the 2015, 2016, and 2017 sustainability reports of Fibria, Suzano, and Veracel, it is remarkable how important land disputes are in the companies' agendas. The topic is explicitly mentioned in at least one of Fibria and Veracel's presidents or board of directors' letters at the beginning of the reports. In Fibria's 2015 report, Marcello Castelli, the CEO, stated: "The land issue in Brazil is very broad and complex..." Land and tenure rights is included in a materiality matrix of both Suzano and Veracel, and considered a material topic for both internal and external audiences.

Throughout the reports, the strategies to clarify, uphold, and protect land rights are explored. The authors identified and classified them into four categories: (a) clarification, upholding, or delimitation of rights between the parties, (b) reallocation of rights between the parties, (c) appeal to a third party to define and enforce property rights, and (d) a combination of strategies $\mathrm{a}, \mathrm{b}$, and c. The result is summarized in Table 3. 
Table 3

Strategy to clear, uphold, and protect land property rights by company

\begin{tabular}{|c|c|c|c|}
\hline $\begin{array}{l}\text { Categories of } \\
\text { strategy/Company }\end{array}$ & Fibria & Suzano & Veracel \\
\hline $\begin{array}{l}\text { (a) clarification, } \\
\text { upholding, or } \\
\text { delimitation of } \\
\text { rights between the } \\
\text { parties }\end{array}$ & $\begin{array}{l}\text { Interlocutor qualification to } \\
\text { hold qualified dialogues with } \\
\text { stakeholders (2015) } \\
\text { Transparent dialogue and } \\
\text { engagement with impacted } \\
\text { communities (2015, 2016, 2017) } \\
\text { Conversations with landless } \\
\text { movement regarding land } \\
\text { invasions in Espírito Santo state } \\
\text { (2016, 2017) } \\
\text { Support to indigenous groups } \\
\text { (2015, 2016, 2017) } \\
\text { Support to family farming (2015, } \\
\text { 2016, 2017) } \\
\text { Support to Afro descendant } \\
\text { groups (quilombolas) (2017) } \\
\text { Tree outgrowers program (2015, } \\
\text { 2016, 2017) }\end{array}$ & $\begin{array}{l}\text { Active dialogue with } \\
\text { stakeholders }(2015,2016, \\
2017) \\
\text { Support to family farming } \\
(2015,2016,2017) \\
\text { Support to babassu coconut } \\
\text { breakers traditional group } \\
(2015,2016,2017)\end{array}$ & $\begin{array}{l}\text { Dialogue and engagement with impacted } \\
\text { communities }(2015,2016,2017) \\
\text { Dialogue agenda with social movements } \\
\text { (2015) } \\
\text { Tree outgrowers program as a strategy to } \\
\text { include farmers in the forest supply chain } \\
\text { and avoid further land acquisition (2015, } \\
2016) \\
\text { Support to traditional communities (2015, } \\
2016) \\
\text { Support to family farming }(2015,2016)\end{array}$ \\
\hline $\begin{array}{l}\text { (b) reallocation of } \\
\text { rights between the } \\
\text { parties }\end{array}$ & $\begin{array}{l}\text { Program for land acquisition by } \\
\text { communities }(2015) \\
\text { Long term goal: reduction by } 1 / 3 \\
\text { in the amount of land to produce } \\
\text { pulp }(2015,2016,2017)\end{array}$ & & Land leasing to family farmers $(2015,2016)$ \\
\hline $\begin{array}{l}\text { (c) appeal to a } \\
\text { third party to } \\
\text { define and enforce } \\
\text { property rights }\end{array}$ & & & $\begin{array}{l}\text { Use of legal mechanism (repossession order) } \\
\text { to recover possession of land invaded by } \\
\text { social movements beyond what was agreed } \\
\text { between the parties (2015) }\end{array}$ \\
\hline $\begin{array}{l}\text { (d) combination } \\
\text { of strategies a, b, } \\
\text { and c }\end{array}$ & $\begin{array}{l}\text { Establishment of agrarian reform } \\
\text { settlements on former company } \\
\text { farms as per agreement with } \\
\text { social movements and multiples } \\
\text { government bodies }(2015,2016 \text {, } \\
2017) \\
\text { Workshops with managers and } \\
\text { community leaders to evaluate } \\
\text { social engagement performance } \\
\text { and review strategies (2017) } \\
\text { Engagement with National } \\
\text { Confederation of Afro } \\
\text { Descendant Communities to } \\
\text { discuss Afro descendants' land } \\
\text { rights (2017) }\end{array}$ & $\begin{array}{l}\text { Establishment of } \\
\text { Communitarian Councils } \\
(2015,2016,2017) \text { that allows } \\
\text { community participation } \\
\text { in some decision-making } \\
\text { processes, enabling the } \\
\text { reduction of occurrences such } \\
\text { as land invasions (2017) }\end{array}$ & $\begin{array}{l}\text { Establishment of agrarian reform settlements } \\
\text { on former company farms as per agreement } \\
\text { with social movements and multiple } \\
\text { government bodies (2015, 2016, 2017) } \\
\text { Setting up a discussion forum (Sala de } \\
\text { Situação) on land conflicts in South Bahia } \\
\text { and public policies on family farming } \\
\text { in agrarian reform settlements with the } \\
\text { participation of multiple public bodies, } \\
\text { social movements, and Veracel (2016) } \\
\text { Engagement with multiple civil society } \\
\text { organizations to clarify company's role and } \\
\text { responsibilities in local development (2015, } \\
\text { 2016) }\end{array}$ \\
\hline
\end{tabular}

Clarification, upholding, and delimitation of rights through dialogue and engagement with stakeholders is a common practice among the three companies (Fibria, 2016, 2017, 2018; Suzano, 2016, 2017, 2018; Veracel, 2016, 2017). In particular, Fibria has offered a qualification to its interlocutors to hold qualified dialogue with stakeholders (Fibria, 2017). They all highlight the importance of face-to-face meetings with communities before running forest operations. In those sessions, the company's impacts and procedures are discussed to minimize them. From the theoretical perspective, these meetings serve, among other purposes, to clarify/inform and to acknowledge property rights on both sides: company and stakeholders. Another common 
practice among them is support to family farming (Fibria, 2016, 2017, 2018; Suzano, 2016, 2017, 2018; Veracel, 2016, 2017) and to traditional community groups (indigenous communities, Afro-descendent groups, babassu coconut breakers, and/or fishing communities), which serves to uphold community rights. The tree outgrowers program mentioned by Fibria and Veracel (Fibria, 2016, 2017, 2018; Veracel, 2016, 2017) also serves to uphold farmers' land rights, to include farmers in the mill supply chain, and to prevent further land acquisition by the company. The same two companies mentioned ongoing engagement with landless social movements to agree on common ground (Fibria, 2017, 2018; Veracel, 2016).

Strategies for the reallocation of rights were mentioned by Fibria and Veracel. In its 2015 annual report, Fibria (Fibria, 2016) mentioned the submission of a pilot project proposal for land acquisition by the community supported by a federal grant program. The land would be acquired from Fibria and from other landowners. The $1 / 3$ reduction in the amount of land needed to supply wood to pulp mills (Fibria, 2017, 2018) would be achieved through genetic breeding and an increase in pulp production yield per hectare. This goal can reduce land concentration and make it available for other uses. In its 2015 and 2016 annual reports, Veracel mentioned its program for land leasing to family farmers (Veracel, 2016, 2017): "Designed to produce food for the community itself to consume... We promote this initiative by means of land assignments in commodatum, on the basis of an agreement reached in the Bahia Forest Forum to share the eucalyptus forests' setback areas near the community" (Veracel, 2017, p. 20).

Only one company mentioned the use of repossession orders to recover land tenures (Veracel, 2016). Most probably, the other companies make use of the same legal provision, but did not mention so.

Finally, the three companies utilize multistakeholder platforms to clarify, uphold, negotiate, and protect land rights. Since it is impossible for the authors to know the preferential strategy employed by the platforms merely through document analysis, the strategies included under the " $d$ " category can include any of the previous strategies ( $a, b$, and $c)$. Two companies mentioned in their reports the program for establishment of land reform settlements on the companies' farms. The platforms include multiple government bodies, the landless social movement, and forest companies (Fibria, 2016, 2017, 2018; Veracel, 2016, 2017): “... we kept up the rhythm of work and dialogue we attained in 2015 with the six social movements involved in the agreement with the National Institute for Colonization and Agrarian Reform (INCRA) and the Bahia State Government" (Veracel, 2017, p. 5). A similar group of stakeholders also participates in another forum that aims to discuss land conflicts in South Bahia and public policies to support family farming in rural settlements (Veracel, 2017). Veracel also mentioned engagement with multiple civil society organizations to discuss the company's contributions in resolving land conflicts in South Bahia (Veracel, 2016, 2017). Fibria mentioned two additional multi-stakeholder platforms to deal with land conflicts: the workshop with managers and community leaders to evaluate the company's social performance and to review its strategic streams: "four large workshops were carried out with the participation of ... strategic areas of the company. Each workshop covered a different subject (indigenous groups, quilombolas, MST (Landless Rural Workers Movement), and employment) and had representatives from each of these communities" (Fibria, 2018, p. 26); and engagement with the National Confederation of Afro Descendant Communities (Confederação Nacional Quilombola - CONAQ) (Fibria, 2018). For Suzano, the Communitarian Councils are the multi-stakeholder platform employed to discuss the various local concerns (Suzano, 2016, 2017, 2018). Through the platform, the community participates in various decision-making processes, resulting in the reduction of land invasions, 
among other achievements: "Increased interaction between communities and the company has led to joint reflections and decision-making ... Today the results are clearly visible, in terms of ... reducing certain occurrences such as wood theft, forest fires, and squatting" (Suzano, 2018, p. 41).

\section{Analysis of Results}

According to the theoretical framework described in section 2, protective mechanisms are deployed by economic agents to prevent rights capture in the presence of unclearly delineated property rights (Barzel, 1997; Dixit, 2004). In a poor institutional environment, the effectiveness of legal protection is attenuated, resulting in the increased relevance of private mechanisms.

Section 3 explored the various vulnerabilities in the Brazilian institutional environment for land rights protection. The limited capacity of the State to define and enforce property rights creates enabling conditions for conflicts.

In section 4 , the literature review shed light on recurrent land disputes in the country between various stakeholder groups (community, indigenous groups, landless movement, Afrodescendant groups, and even State) and forest companies. Those conflicts were called pathologies and they reflect the dispute for rights allocated in the public domain. In addition, the literature review provided the names of the forest companies most frequently associated with land rights in Brazil.

A wide range of strategies for the three companies to deal with land conflicts was identified in the sustainability reports (section 5). Just one of them stated it made use of a third party to define and enforce property rights (category c), this third party being the State. All other strategies listed in the sustainability reports are private mechanisms to define, uphold, and protect land rights. The most extensive list of strategies was found under category (a): clarification, upholding, or delimitation of rights between the parties. According to Barzel (1997), people use the lowest-cost methods available to them under the constraints to reclaim the value that the regulations place in the public domain. Two other avenues for dealing with land disputes employing private mechanisms were (b) reallocation of rights between the parties and (d) a combination of strategies a, b, and c. Although it was not mentioned in the reports, a gradation of complexity (decision-making in a large group of participants) and cost is expected to be found among strategies $\mathrm{a}, \mathrm{b}$, and $\mathrm{d}$. Only complex cases are dealt with by the mechanisms included in category d. Strategies included under categories (a) and (b) count on bilateral self-enforcement by a pair of agents; and category (d) counts on multilateral self-enforcement in a community of agents coexisting in the same setting, according to the private institutions of economic governance studied by Dixit, (2004, 2009).

In short, the empirical findings are consistent with the rationale proposed by the Economic Analysis of Property Rights. The contribution of this paper was to comprehend how capture attempts take place and what private mechanisms are employed by firms in the forest sector in Brazil.

\section{Conclusion}

This paper aimed to address two points: what are the pathologies associated with poor legal protection of land rights in Brazil and what are the strategies deployed by forest companies to solve land disputes?

The most frequent pathologies reported by the literature are the ones involving local communities, indigenous groups, Afro-descendant groups, and the landless movement, and the ones related to land title regularization procedures or land acquisition facilitation by the government, to possession of vacant public land, and to superposition of land titles.

The business strategies used by the forest companies to address land rights are numerous. The review of three years of sustainability 
reports of Fibria, Suzano, and Veracel revealed the following avenues of actions: numerous initiatives to promote clarification, upholding, and delimitation of rights through dialogue and engagement with stakeholders, where land rights are discussed at the field level on a recurrent basis; a smaller group of initiatives aiming to reallocate rights between parties; limited use of a third party (State) to define and enforce property rights; and multiple multi-stakeholder platforms to engage different actors in the creation of solutions to land disputes affecting the parties. The Economic Analysis of Property Rights founded by Barzel (1989, 1997, 2002), and further developed by Dixit (2004, 2009) and Zylbersztajn (2010, 2012), was helpful in understanding the coexistence of this spectrum of strategies.

This study has many limitations. First of all, it relied only on a publications review, leading to bias in the analysis, since the sustainability reports present information from the companies' perspective and the academic publications reference only seven companies. Future studies in this field should include additional data sources. Secondly, the business cases of three large-scale certified forest operations may not represent the universe of companies operating in Brazil. Hence, future studies should look at reviewing data for a larger number of organizations. Thirdly, only the number of business strategies per category was analyzed, without taking into account their impact, such as on the number of conflicts addressed through each channel, the number of stakeholders impacted, or the size of the land under dispute. Finally, future studies could compare the institutional environment and business strategies for land rights protection across countries, sub regions of the same country, or across sectors.

Despite the limitations, this paper has shed light on the interconnection between the institutional environment, land conflicts, and business strategy to protect land rights.

\section{References}

Acemoglu, D., Johnson, S., \& Robinson, J. A. (2001). The colonial origins of comparative development: an empirical investigation. The American Economic Review, 91(5), 1369-1401.

Alston, L. J., Harris, H., \& Mueller, B. (2009). De Facto and De Jure Property Rights: Land Settlement and Land Conflict on the Australian, Brazilian and U.S. Frontiers. SSRN Electronic Journal, 1. https://doi.org/10.2139/ssrn.1474025

Araujo, C., Bonjean, C. A., Combes, J. L., Combes Motel, P., \& Reis, E. J. (2009). Property rights and deforestation in the Brazilian Amazon. Ecological Economics, 68(8-9), 2461-2468. https://doi.org/10.1016/j.ecolecon.2008.12.015

Barzel, Y. (1989). Economic Analysis of Property Rights. Cambridge University Press New York.

Barzel, Y. (1997). Economic Analysis of Property Rights ( $2^{\text {nd }}$ edition). New York: Cambridge University Press.

Barzel, Y. (2002). The theory of the state Economic rights, legal rights and the scope of the state. New York: Cambridge University Press.

Brasil. (1988). Constituição da República Federativa do Brasil de 1988. Retrieved February 27, 2017, from http://www.planalto.gov.br/ ccivil_03/constituicao/constituicao.htm

Claro, P. B. O. (2007). Direito de propriedade, atividades econômicas e contexto institucional no vale do Jari. Universidade Federal de Lavras.

Comissão Pastoral da Terra. (2016). Conflitos no Campo Brasil. Retrieved February 20, 2017, from https://www.cptnacional.org.br/index. $\mathrm{php} /$ publicacoes-2/destaque/3175-conflitos-nocampo-brasil-2015

de Soto, H. (2000). The Mystery of capital: why capitalism triumphs in the west and fails everywhere. New York: Basic Books. 
Deininger, K., \& Jin, S. (2007). Securing property rights in transition: lessons from implementation of China's rural land contracting law (No. 4447). Policy research working paper (Vol. 70). https:// doi.org/10.1016/j.jebo.2009.01.001

Dellagnelo, E. H. L., \& Silva, R. C. da. (2005). Análise de conteúdo e sua aplicação em pesquisa na administração. In M. M. F. Vieira \& D. M. Zouain (Eds.), Pequisa qualitativa em administraçâo teoria e prática (p. 240). Rio de Janeiro: Fundação Getúlio Vargas.

Dixit, A. (2004). Lawlessness and Economics Alternative Modes of Governance. Princeton: Princeton University Press.

Dixit, A. (2009). Governance Institutions and Economic Activity. American Economic Review, 99(1), 5-24. https://doi.org/10.1257/aer.99.1.5

Elkington, J. (1994). Towards the sustainable corporation: win-win-win business strategies for sustainable development. California Management Review, 36(2), 90-100. https://doi.org/https:// doi.org/10.2307/41165746

Fibria. (2016). Relatório Fibria 2015. Retrieved from http://www.fibria.com.br/comunicacao/ relatorios-anuais/

Fibria. (2017). Relatório Fibria 2016 Um novo horizonte para todos.

Fibria. (2018). Fibria relatório 2017 uma floresta de oportunidades. Retrieved from http://www. fibria.com.br/comunicacao/relatorios-anuais/

Fig, D. (2007). Questioning CSR in the Brazilian Atlantic Forest : the case of, 28(4), 831-849. https://doi.org/10.1080/01436590701336705

Gerber, J.-F. (2011). Conflicts over industrial tree plantations in the South: Who, how and why? Global Environmental Change, 21, 165-176. https://doi.org/10.1016/j. gloenvcha.2010.09.005
Graça, C. T., Reydon, B. P., Postal, A. M., Bueno, A. P. da S., \& Moreira, G. L. (2017). Fragilidade dos direitos de propriedade no Brasil: diagnóstico e estimativa de alguns custos para o setor florestal. In B. P. Reydon, V. B. Fernandes, A. P. da S. Bueno, \& G. P. Siqueira (Eds.), Governança de Terras: da teoria à realidade brasileira ( $\mathrm{p}$. 378). Organização das Nações Unidas para a Alimentação e a Agricultura. Retrieved from http://www.fao.org/3/a-i7789o.pdf

Indústria Brasileira de Árvores. (2017). Relatório 2017. Retrieved from http://iba.org/images/ shared/Biblioteca/IBA_RelatorioAnual2017.pdf

Kröger, M. (2011). Promotion of contentious agency as a rewarding movement strategy: evidence from the MST-paper industry conflicts in Brazi, 38(2), 435-458. https://doi.org/10.10 $80 / 03066150.2011 .559016$

Kröger, M. (2012). The Expansion of Industrial Tree Plantations and Dispossession in Brazil. Development and Change, 43(4), 947-973. https:// doi.org/10.1111/j.1467-7660.2012.01787.x

Kröger, M. (2013). Grievances, agency and the absence of conflict: The new Suzano pulp investment in the Eastern Amazon. Forest Policy and Economics, 33, 28-35. https://doi. org/10.1016/j.forpol.2013.02.005

Kröger, M. (2014). The political economy of global tree plantation expansion: a review. The Journal of Peasant Studies, 41(2), 235-261. https://doi.org/10.1080/03066150.2014.890596

Kröger, M., \& Nylund, J. (2012). The con flict over Veracel pulpwood plantations in Brazil - Application of Ethical Analysis. Forest Policy and Economics, 14(1), 74-82. https://doi. org/10.1016/j.forpol.2011.07.018

Malina, L. L. (2013). A territorializaçâao do monopólio no setor celulistico-papeleiro: a atuação da Veracel Celulose no Extremo Sul da Bahia. University of São Paulo. 
North, D. C. (1990). Institutions, institutional change, and economic performance. New York: Cambridge University Press.

Reydon, B. P. (2011). A questão agrária brasileira requer solução no século XXI. In As questóes agrária e da infraestrutura de transporte para o agronegócio (pp. 3-48). Viçosa: Universidade Federal de Viçosa.

Reydon, B. P. (2014). Governança de terras e a questão agrária no Brasil. In A. M. Buainain, E. Alves, J. M. Silveira, \& Z. Navarro (Eds.), O mundo rural no Brasil do século 21, a formação de um novo padrão agrário e agrícola (p. 1182). Brasília: Embrapa.

Reydon, B. P., Fernandes, V. B., \& Telles, T. S. (2015). Land tenure in Brazil: The question of regulation and governance. Land Use Policy, 42, 509-516. https://doi.org/10.1016/j. landusepol.2014.09.007

Silva, L. O. (1997). As Leis agrárias e o latifúndio improdutivo. São Paulo Em Perspectiva, 11(2), $15-25$.

Suzano. (2016). Relatório de Sustentabilidade 2015. Retrieved from http://ri.suzano.com.br/acompanhia/sustentabilidade

Suzano. (2017). Relatório de sustentabilidade 2016. Retrieved from http://ri.suzano.com.br/acompanhia/sustentabilidade

Suzano. (2018). Relatório de sustentabilidade 2017. Retrieved from http://ri.suzano.com.br/acompanhia/sustentabilidade
Veracel. (2016). Relatório de sustentabilidade 2016 ano base 2015.

Veracel. (2017). Relatório de sustentabilidade 2017 ano-base 2016. Retrieved from http:// www.veracel.com.br/sobre-a-veracel/relatorio-desustentabilidade/

World Bank. (2014). Avaliação da Governança Fundiária no Brasil. Retrieved from http:// siteresources.worldbank.org/INTLGA/ Resources/Brazil_land_governance_assessment_ final_Portuguese.pdf

Yin, R. K. (2010). Estudo de caso planejamento e método ( $4^{\text {th }}$ ed.). Bookman.

Zylbersztajn, D. (2010). Fragile Social Norms : (Un) Sustainable Exploration of Forest Products. International Journal on Food System Dynamics, 1(March), 46-55.

Zylbersztajn, D. (2012). Reallocation of property rights in agro-food systems: addressing diffuse stakeholders' rights. Journal of Chain and Network Science, 12(01), 1-12. https://doi.org/10.3920/ JCNS2012.x211

\section{Note}

1 Votarantin group acquired Aracruz Celulose in 2009. After that, the two companies together became Fibria. 
About the Authors:

1. Carolina Torres Graça, PhD candidate in Business Administration, University of São Paulo, São Paulo Brazil, E-mail: ctgraca11@gmail.com

\section{ORCID}

(iD) 0000-0002-0127-9280

2. Decio Zylbersztajn, PhD, University of Sao Paulo, São Paulo, Brazil, E-mail: dezylber@usp.br ORCID

(iD) 0000-0002-4007-4958

Has any preliminary version of this article been presented / published in annals of scientific congresses or is it derived from a thesis or dissertation?

A preliminary version of this paper was presented at the $56^{\text {th }}$ Congress organized by the Brazilian Society for Rural Economics, Business Administration and Sociology (SOBER)

\section{Contribution of each author}

\begin{tabular}{lcc}
\hline Contribution & Carolina Graça & Decio Zylbersztajn \\
\hline 1. Definition of research problem & $\sqrt{ }$ & $\sqrt{ }$ \\
2. Development of hypotheses or research questions (empirical studies) & $\sqrt{ }$ & $\sqrt{ }$ \\
3. Development of theoretical propositions (theoretical work) & $\sqrt{ }$ & $\sqrt{ }$ \\
4. Theoretical foundation/Literature review & $\sqrt{ }$ \\
5. Definition of methodological procedures & $\sqrt{ }$ \\
6. Data collection & $\sqrt{ }$ \\
7. Statistical analysis & $\sqrt{ }$ \\
8. Analysis and interpretation of data & $\sqrt{ }$ \\
9. Critical revision of the manuscript & $\sqrt{ }$ \\
10. Manuscript writing & \\
11. Other (please specify which) & \\
\hline
\end{tabular}

